\title{
Koncepcja świętości w noweli Pauli von Preradović pt. Die Versuchung des Columba
}

\section{The Conception of Holiness in Paula von Preradović's Novella Die Versuchung des Columba [The Temptation of Saint Columba]}

\begin{abstract}
Paula von Preradović's literary output consists mainly of poems, including the lyrics for the national anthem of Austria, Land der Berge, Land am Strome [Land of the mountains, land on the river] (1946/1947), but she also wrote several novellas, autobiographical sketches, small scenic works and journalistic texts, as well as one novel. This article investigates the conception of holiness in Preradović's novella Die Versuchung des Columba. Saint Columba, the protagonist of the novella, was an Irish abbot and missionary. He is remembered today as a Catholic saint and one of the Twelve Apostles of Ireland. The analysis focuses on the character of Columba, his behaviour, actions, development and the psychological stages he has gone through. Preradović explains her conception of holiness with the example of Columba's life. She does not define holiness as infallibility, but primarily as integrity and a sense of responsibility for fellow men. The author describes it as that virtue by which one makes all one's acts subservient to God. She ranks it among the infused moral virtues.
\end{abstract}

Keywords: Paula von Preradović, holiness, Austrian literature, Saint Columba, Celtic Christianity

Abstrakt: Dorobek literacki Pauli von Preradović stanowią głównie wiersze, w tym teksty do hymnu narodowego Austrii Land der Berge, Land am Strome (1946/1947), pisarka ma też na koncie kilka nowel, szkice autobiograficzne, drobne utwory sceniczne i teksty publicystyczne, a także jedną powieść. Niniejszy artykuł bada koncepcję świętości w noweli Preradović Die Versuchung des Columba. Święty Kolumban, bohater noweli, był irlandzkim opatem i misjonarzem. Dziś jest pamiętany jako katolicki święty i jeden z Dwunastu Apostołów Irlandii. Niniejsza analiza koncentruje się na charakterze Kolumbana, jego zachowaniu, działaniach, rozwoju oraz etapach psychologicznych, przez jakie przeszedł. Preradović tłumaczy swoją koncepcję świętości na przykładzie życia Kolumbana. Nie definiuje świętości jako nieomylności, ale przede wszystkim jako integralność i poczucie odpowiedzialności za bliźnich. Autorka opisuje ją jako cnotę, dzięki której wszystkie swoje czyny podporządkowuje się Bogu. Zalicza ją do natchnionych cnót moralnych.

Słowa kluczowe: Paula von Preradović, świętość, literatura austriacka, św. Kolumban (opat z Hy), Kościół iroszkocki 
Paula von Preradović (1887-1951), autorka wiersza Land der Berge, Land am Strome [Kraju gór, kraju nad rzeką] (1946/1947), który stał się tekstem hymnu Republiki Austrii, posiada bogaty, lecz mało znany dorobek literacki, powstały głównie w okresie międzywojennym, w trakcie II wojny światowej i tuż po jej zakończeniu. Pozostawiła po sobie wiele utworów lirycznych. Do jej najważniejszych dzieł prozatorskich należą takie teksty, jak powieść Pave und Pero [Pave i Pero] (1940), nowela Königslegende [Legenda królewska] (1950) oraz nowela Die Versuchung des Columba [Kuszenie Kolumbana] (1951).

Jeszcze przed I wojną światową Paula von Preradović oddaliła się od Kościoła, jednak po kilkunastu latach zaczęła na nowo odkrywać swoją wiarę. W połowie lat 20. nawiązała kontakt $\mathrm{z}$ artystami, którzy w Wiedniu założyli krąg literacki o nazwie «Leo-Stube». Główną rolę odgrywał w tym środowisku Heinrich Suso Waldeck, katolicki ksiądz, poeta i kompozytor1. Wśród członków kręgu znalazła się grupa osób zaangażowanych w działania «Akcji Katolickiej», ruchu katolików świeckich, który stawiał sobie za cel wprowadzenie wartości chrześcijańskich do życia publicznego ${ }^{2}$.

Wiersze Preradović z tego okresu odzwierciedlają przemiany, które zaszły w jej światopoglądzie i twórczości literackiej. Zawierają one liczne motywy chrześcijańskie rzadko występujące we wcześniejszych tekstach. W tomiku zatytułowanym Lob Gottes im Gebirge (1936) myśl chrześcijańska odgrywa ważną rolę. Zawarte w nim wiersze dają czytelnikowi wyobrażenie o programie literackim pisarki w ostatnich piętnastu latach jej życia.

Wydarzeniem, które wywarło znaczący wpływ na jej twórczość, było nawiązanie kontaktu z katolicką organizacją młodzieżową «Bund Neuland»», której członkowie założyli w Wiedniu dwie szkoły ${ }^{4}$. Jedną z nich była szkoła w dzielnicy Döbling, do której uczęszczał Fritz Molden, młodszy syn pisarki. Przyjaźń z Karlem Rudolfem, współzałożycielem organizacji, sprawiła, że Paula von Preradović jeszcze bardziej zbliżyła się do Kościoła ${ }^{5}$.

Uczestnicząc w spotkaniach kręgu biblijnego, działającego przy parafii katedralnej pw. św. Szczepana w Wiedniu, nie tylko pogłębiała swoją wiedzę reli-

\footnotetext{
${ }^{1}$ Zob. E. Molden, Skizzen zu einem Porträt [w:] Paula von Preradović. Porträt einer Dichterin, Innsbruck 1955, s. 9-82, tutaj: s. 42.

${ }^{2}$ Zob. W. Röttinger, Vorwort [w:] P. v. Preradović, Meerferne Heimat. Eingeleitet und ausgewählt von Werner Röttinger, Graz-Wien 1961, s. 5-23, tutaj: s. 12.

3 «Bund Neuland» - austriacka organizacja katolicka, która została założona w roku 1919 przez Karla Rudolfa i Michaela Pfliegera. Stawiała sobie za cel ochronę młodzieży przed sekularyzacją oraz propagowanie wartości chrześcijańskich. Wydawała czasopismo „Neue Jugend” oraz wspierała rozwój «Ruchu liturgicznego» - nurtu teologii zmierzającego do odnowienia praktyki sakramentalnej i życia modlitwy Kościoła katolickiego. W 1938 roku została rozwiązana, reaktywowano ją dziesięć lat później (zob. E. Bruckmüller (red.), Österreich-Lexikon in drei Bänden, Wien 2004; hasło: Neuland, t. I, s. 475). Do najbardziej znanych członków, którzy wywarli znaczący wpływ na życie kulturalne i polityczne Austrii, należeli Joseph Ernst Mayer, Otto Mauer, Ida Friederike Görres oraz Felix Hurdes (zob. F.M. Kapfhammer, Neuland. Erlebnis einer Jugendbewegung, Graz-Wien (i inne) 1987, s. 179-233). Założone przez «Bund Neuland» szkoły w dzielnicach Grinzing (Döbling) i Laaerberg funkcjonują do dnia dzisiejszego.

${ }^{4}$ Zob. E. Molden, op. cit., s. 56.

${ }^{5}$ Zob. ibid.
} 
gijną, ale także nawiązała kontakty z pisarkami chrześcijańskimi, takimi jak Oda Schneider i Ida Friederike Görres ${ }^{6}$. Temat świętości - rozumianej jako odpowiedź na łaskę i życie blisko Boga, dostępne każdemu człowiekowi, niezależnie od przynależności do klasy społecznej, stopnia zamożności i wykonywanego zawodu - był w tym okresie dla Pauli von Preradović bardzo istotny.

Członkowie organizacji «Bund Neuland» wypracowali własny sposób na urzeczywistnienie postulatu świętości, polegający na realizacji indywidualnego powołania przez pracę nad sobą, sumienne wykonywanie obowiązków, unikanie grzechu, doskonalenie cnót, dzielenie się radością wiary oraz wytrwałe znoszenie cierpienia. Na pojmowanie świętości jako czegoś powszechnie dostępnego, do czego powołani są wszyscy wierzący i co może stać się udziałem każdego człowieka, zwrócili uwagę kilkadziesiąt lat później ojcowie Soboru Watykańskiego II. Dzięki preferowanemu w «Bund Neuland» wychowaniu młodzieży do miłości Boga i bliźniego wielu członków i sympatyków tej organizacji przyjęło styl życia nakierowany na apostolstwo oraz zaangażowanie społeczne. Dostrzegali oni jednak nie tylko potrzebę ewangelizacji i upowszechniania w świecie wartości chrześcijańskich. Dużą wagę przykładali do rozwoju wewnętrznego jako nieodłącznego elementu dążenia do świętości. Zdając sobie sprawę z zagrożeń, które niesie ze sobą współczesny świat, zwracali uwagę na szczególną wartość pracy nad sobą i wzrostu duchowego - drogowskazu pozwalającego odnaleźć młodzieży właściwą drogę życiową.

Aby lepiej zrozumieć program ideowy organizacji «Bund Neuland», jak również koncepcję rozwoju duchowego i dążenia do świętości, warto pochylić się nad wybranymi fragmentami książki Jana Pawła II zatytułowanej Pamięć i tożsamość. Rozmowy na przełomie tysiącleci (2005), w której koncepcja ta została rozwinięta. Choć tekst powstał ponad pół wieku po założeniu «Bund Neuland», to koresponduje on z katolickimi prądami myślowymi lat 30. i 40. XX wieku, co wydaje się zrozumiałe zważywszy na fakt, iż w tym właśnie okresie kształtowała się duchowość młodego Karola Wojtyły. W zbiorze refleksji filozoficznych i historycznych Jana Pawła II odnajdujemy następujący passus:

W tajemnicy odkupienia zwycięstwo Chrystusa nad złem jest dane człowiekowi [...] także jako zadanie. Człowiek podejmuje je, wchodząc na drogę życia wewnętrznego, to znaczy na drogę świadomej pracy nad sobą - tej pracy, w której Mistrzem jest Chrystus. Ewangelia wzywa człowieka do pójścia tą właśnie drogą $[\ldots]^{7}$.

Autor twierdzi, iż człowiek podążający drogą świętości zyskuje odwagę i niezależność. Przestaje bać się grzechu i zaczyna dostrzegać dobro stworzenia, które stanowi odbicie Bożej doskonałości. Pisze o tym następująco:

Z biegiem czasu, jeżeli człowiek wytrwale postępuje za Mistrzem [...], coraz mniej odczuwa ciężar zwalczania w sobie grzechu, a coraz bardziej raduje się światłem Bożym, które przenika całe stworzenie. Jest to ogromnie ważne, gdyż pozwala człowiekowi wyjść z sytuacji nieustannego zagrożenia wewnętrznego przez grzech - który jednak na tej ziemi w jakimś stopniu pozostaje zawsze obecny - i poruszać się coraz swobodniej pośród całego

\footnotetext{
${ }^{6}$ Zob. ibid., s. 57.

7 Jan Paweł II, Pamięć i tożsamość. Rozmowy na przełomie tysiącleci, Kraków 2005, s. 33.
} 
stworzonego świata. [...] Człowiek we wszystkim znajduje Boga, we wszystkim i poprzez wszystko z Nim obcuje. Rzeczy stworzone przestają być dla niego zagrożeniem [...]. Rzeczy, a w szczególności osoby, nie tylko odzyskują właściwe sobie światło, które w nich zawarł Bóg jako Stwórca, ale $[\ldots]$ «udostępniają» Boga samego $[\ldots]^{8}$.

Jan Paweł II rozważa konsekwencje, które pociągają za sobą ideologie XX wieku, oraz zastanawia się nad perspektywą wolności uzyskanej przez obywateli państw rządzonych niegdyś totalitarnie. Dostrzega, iż zagrożenie złem związanym ze wspomnianymi ideologiami nadal istnieje. Na świecie pojawiają się jednak nowe problemy, spośród których największym jest niewłaściwe użycie przez człowieka wolności ${ }^{9}$. Autor twierdzi, iż niebezpieczeństwo obecnej sytuacji polega na abstrahowaniu od etycznego wymiaru wolności oraz na odwracaniu uwagi człowieka od odpowiedzialności etycznej ${ }^{10}$. Odwołując się do różnych nurtów filozofii europejskiej, w tym także do myśli oświeceniowej, Jan Paweł II podkreśla, iż istnieją kryteria używania wolności, natomiast akty ludzkie domagają się odpowiedzialności podmiotu ${ }^{11}$.

Paula von Preradović żyła w czasach, kiedy zagadnienia te były nadzwyczaj aktualne ze względu na zagrożenie Austrii nazizmem i komunizmem. Wychowując młodych w duchu chrześcijańskim, organizacja «Bund Neuland» próbowała uchronić ich przed niebezpieczeństwami ówczesnego świata, a zwłaszcza przed wpływami ideologii totalitarnych. Droga wzrostu duchowego, wychowania do świadomego podejmowania decyzji i dążenia do świętości wydawała się członkom organizacji najlepszą odpowiedzią na problemy tamtego okresu. Pod wpływem kręgu literackiego «Leo-Stube» oraz organizacji młodzieżowej «Bund Neuland» Paula von Preradović zaczęła kształtować własny obraz świętości, inspirowany duchowością środowiska, z którym utrzymywała kontakty. Można go odnaleźć w jej twórczości, zwłaszcza w tekstach z lat 30., 40. i początku lat 50. Nie to będzie jednak celem analizy noweli Die Versuchung des Columba.

Zastanawiając się nad tym, jaka tradycja teologiczna mogła inspirować twórczość austriackiej autorki, warto zwrócić uwagę na wydane w roku 1917 dzieło niemieckiego teologa i filozofa Rudolfa Otto Das Heilige. Über das Irrationale in der Idee des Göttlichen und sein Verhältnis zum Rationalen [Świętość. Elementy irracjonalne w pojęciu bóstwa i ich stosunek do elementów racjonalnych]. Szeroka recepcja tego tekstu w okresie międzywojennym pozwala przypuszczać, że Paula von Preradović znała go, choć pojęcie świętości w nim sformułowane różni się w znacznym stopniu od tego, które odnajdujemy w jej twórczości. Dla Rudolfa Otto sanctus oznacza bowiem "ponadświatowy»" ${ }^{12}$ i nie jest kategorią moralną ${ }^{13}$. Teolog podkreśla, że „[...] przywykliśmy posługiwać się słowem «święty» w znaczeniu, które jest jego znaczeniem całkowicie przenośnym i bynajmniej nie

${ }^{8}$ Ibid., s. 35-38.

9 Zob. ibid., s. 41.

${ }^{10}$ Zob. ibid., s. 41-42.

${ }^{11}$ Zob. ibid., s. 42.

${ }^{12}$ Rudolf Otto łączy pojęcie świętości z utworzoną przez siebie kategorią «numinosum».

${ }^{13}$ Zob. R. Otto, Świętość. Elementy irracjonalne w pojęciu bóstwa i ich stosunek do elementów racjonalnych, przeł. B. Kupis, Warszawa 1999, s. 9-11. 
pierwotnym"14. Mimo że rozumiemy świętość zazwyczaj ,jako absolutny moralny orzecznik, jako «doskonale dobry»"15, to właśnie transcendentny składnik świętości jest, zdaniem Otta, właściwym jej wyznacznikiem. Nawet jeśli kierunek myślenia członków «Leo-Stube» wraz z jego orientacją na sztukę, piękno i sakralność poezji jest blisko związany z myśleniem niemieckiego teologa, to trudno doszukiwać się zbieżności w sposobie rozumienia świętości między nim a Paulą von Preradović.

Tekst, który zamierzam poddać analizie, odwołując się do opublikowanej przeze mnie w 2016 roku pracy zatytułowanej Das christliche Weltbild in der Prosa der österreichischen Dichterin Paula von Preradović [Światopogląd chrześcijański w prozie austriackiej pisarki Pauli von Preradović], poświęcony jest Kolumbanowi Starszemu ${ }^{16}$, jednemu z dwunastu apostołów Irlandii oraz świętemu Kościoła katolickiego i anglikańskiego. Zanim jednak przedstawię problematykę noweli, nakreślę podstawy metodologiczne analizy. W moich wywodach odwołam się do rozważań na temat świętości czterech współczesnych teologów: wspomnianego już papieża, teologa moralnego, etyka i przedstawiciela personalizmu chrześcijańskiego Jana Pawła II, teologa duchowości i hagiologa Ireneusza Werbińskiego, teologa dogmatycznego Christopha Schönborna oraz specjalisty z zakresu mistyki karmelitańskiej i teologa pastoralnego Güntera Benkera. Celem analizy nie będzie spojrzenie na nowelę przez pryzmat biografii autorki ani też wykazanie związku między duchowością środowiska, w którym się obracała, a warstwą teologiczną noweli. Tego rodzaju próba byłaby skazana na niepowodzenie, gdyż z powodu braku niezbędnych informacji rozważania opierałyby się zbyt często na domysłach, co stawiałoby pod znakiem zapytania naukowy charakter analizy. Zamiast tego zamierzam przyjrzeć się zjawisku świętości, które stopniowo odsłania się przed czytelnikiem w trakcie lektury noweli. Będzie to zatem analiza oparta na oglądzie tego, co jest bezpośrednio dane w tekście. Odsunięcie na bok założeń wstępnych - niejako w duchu redukcji fenomenologicznej ${ }^{17}$ - otwiera nowe możliwości interpretacyjne. Pozwala bowiem odwołać się do dorobku współczesnych teologów, których myśl koresponduje z koncepcją świętości przedstawioną w noweli austriackiej autorki. Ograniczenie się do rozważań teologów, których teksty były, albo przynajmniej mogły być recypowane w kręgu osób związanych

14 Ibid., s. 9.

15 Ibid.

16 Kolumban Starszy (Kolumban, opat z Hy (Iona)) (521-597) - irlandzki opat, jeden z dwunastu apostołów Irlandii, patron tego kraju (obok św. Patryka i św. Brygidy), święty Kościoła katolickiego i anglikańskiego. Pochodził z panującego w VI wieku rodu królewskiego Uí Néill. Po zakończeniu nauki i otrzymaniu święceń kapłańskich zaczął zakładać klasztory. Wraz z dwunastoma towarzyszami opuścił w roku 563 Irlandię, tworząc na wyspie Iona opactwo. Z tego miejsca podróżował do Nortumbrii, gdzie prowadził pracę misyjną wśród Piktów. Na terenie Szkocji założył kilkadziesiąt klasztorów. Kult św. Kolumbana cieszył się w średniowieczu dużą popularnością w całej Europie. Obecnie nadal odgrywa ważną rolę w Irlandii i Szkocji (zob. W. Kasper (red.), Lexikon für Theologie und Kirche, Freiburg im Breisgau-Wien (i inne) 1994; hasło: Columba(n) v. Hy (autor: Karl Suso Frank), t. II, s. 1267).

17 Zob. M. Maren-Grisebach, Methoden der Literaturwissenschaft, München 1973, s. 42. 
$\mathrm{z}$ «Leo-Stube» $\mathrm{i}$ «Bund Neuland», nie wydaje się przy wyborze takiej metodologii niezbędne.

Protagonista noweli Pauli von Preradović żyje z grupą mnichów na samotnej wyspie należącej do archipelagu Hebrydów. Pewnego dnia przybywa do niego Maurinn, młoda kobieta z irlandzkiego rodu królewskiego, która - powołując się na obietnicę daną jej rodzinie i nie zważając na fakt, iż Kolumban przyjął święcenia kapłańskie - pragnie go poślubić. Początkowo mnich stanowczo odmawia, z czasem zaczyna jednak wątpić w słuszność swojej decyzji. Tęskniąc za Irlandią, krewnymi i ciepłem domowego ogniska, uświadamia sobie swoją słabość. Głos serca kłóci się z poczuciem odpowiedzialności za wspólnotę zakonną i dzieło chrystianizacji Szkocji. Gdy znajduje się już na skraju zwątpienia, wiatr rozwiewa zaczarowane przez celtycką wróżkę zioła, które podarowała mu Maurinn. Pokusa nagle ustępuje, a mnich zdaje sobie sprawę, że własnymi siłami nie jest w stanie niczego osiągnąć i że musi w pełni powierzyć się Bogu. Maurinn, która również uznaje swój błąd, udaje się na skalistą wysepkę w celu odbycia pokuty. Odcięta w wyniku szalejącego przez wiele dni sztormu od dostaw wody i żywności, umiera w swojej pustelni.

Preradović czerpie informacje o misjonarzu Piktów ${ }^{18} \mathrm{z}$ piśmiennictwa religijnego, przedstawia go jednak zupełnie inaczej, niż czynili to autorzy tekstów hagiograficznych. Kolumban jest postacią plastyczną. W noweli zostały ukazane nie tylko jego pozytywne cechy, ale także negatywne, co dodaje bohaterowi autentyzmu. Opisując konflikty wewnętrzne, Preradović rezygnuje z idealizacji tej postaci, dzięki czemu jest ona bliższa czytelnikowi. Pozwala to lepiej zrozumieć istotę ludzkiej egzystencji wraz z jej dylematami. Jednocześnie umożliwia wyciągnięcie wniosków na temat rozumienia pojęcia świętości przez samą autorkę.

Pisarka posłużyła się w noweli plastycznym językiem narracji, dokonując w wielu miejscach archaizacji i stosując charakterystyczny dla jej prozy zabieg stylistyczny polegający na wyrażaniu tych samych treści za pomocą dwóch lub trzech wyrazów bliskoznacznych. Pojawiają się także aliteracje, które nadają niektórym fragmentom podniosły, poetycki charakter. Tekst ma przejrzystą, jednowątkową strukturę i nawiązuje pod tym względem do średniowiecznych legend oraz żywotów świętych. Podczas lektury rzucają się w oczy związki intertekstualne z księgami biblijnymi, zwłaszcza z Księga Hioba, Ewangelia Jana i Księga Psalmów.

Zdaniem teologa, ks. prof. Ireneusza Werbińskiego, świętość należy rozpatrywać na dwa sposoby. Na płaszczyźnie mistycznej świętość jest darem Boga i wezwaniem skierowanym do człowieka, na płaszczyźnie ascetycznej natomiast jest

\footnotetext{
18 Piktowie - grupa plemion pochodzenia celtyckiego, zamieszkujących od X wieku p.n.e. do IX wieku n.e. ziemie północnej Irlandii i Kaledonii. Ich nazwa pochodzi prawdopodobnie od łacińskiego słowa picti (,malowani”) - wojownicy dekorowali ciała tatuażami. W VI wieku zostali nawróceni na wiarę chrześcijańską przez misjonarzy iroszkockich. Ważną rolę w dziele chrystianizacji Piktów odegrał św. Kolumban. We wczesnym średniowieczu utworzyli królestwo, które około 844 roku połączyło się z królestwem Szkotów (zob. W. Kryszewski, R. Marcinkowski (red.), Encyklopedia powszechna PWN, Warszawa 1985; hasło: Piktowie, t. III, s. 535).
} 
odpowiedzią człowieka na Boże wołanie ${ }^{19}$. Bóg proponuje człowiekowi wybór określonej drogi, szanując jego wolność. Oznacza to, że o ile każdy ma możność realizacji świętości, o tyle nikt nie zostaje zmuszony do współpracy z Bogiem ${ }^{20}$. Św. Bazyli Wielki powiada, że ,[...] święty to miejsce odpowiednie dla Ducha, gdy oddaje siebie do zamieszkania Bogu i nazywa się Jego świątynią"21. Odwołując się do pism Ojców Kościoła, arcybiskup Wiednia, kardynał Christoph Schönborn, zwraca uwagę na rolę łaski na drodze do świętości. „Łaska podnosi nas na wyższy poziom i daje nam podobieństwo do Boga; uzdalnia nas do przyjęcia szczęścia nieskończonego, Bożej szczęśliwości [...]"22, twierdzi austriacki teolog. Podkreśla, że przebóstwić człowieka może tylko Bóg. Człowiek nie jest w stanie tego dokonać ${ }^{23}$. Przebóstwienie pozostaje ,rzeczywistym celem, dla którego człowiek został stworzony" ${ }^{24}$, powtarza kardynał Schönborn za greckim teologiem, Maksymem Wyznawcą. Bóg zaszczepił w człowieku tęsknotę za przebóstwieniem, która jednak zamknięta sama w sobie i wynaturzona może człowieka zniszczyć25. „,Otwarta na właściwy cel, może przyjąć szczęśliwość Boga - jedyną skuteczną odpowiedź na ludzkie aspiracje" "26, pisze Schönborn. Nawet jeśli człowiek wpadnie w błąd samoubóstwienia, nie przestaje dążyć do „Bożej szczęśliwości”27, gdyż to właśnie do niej został stworzony. Opisane powyżej koncepcje świętości odnajdujemy w noweli Pauli von Preradović.

W ciągu zaledwie kilku dni Kolumban doświadcza głębokiej przemiany wewnętrznej, dzięki której zmienia się także jego własne pojmowanie świętości. Na pierwszych stronach tekstu irlandzki opat zostaje ukazany nie tylko jako człowiek o szlachetnym pochodzeniu, lecz także jako osoba obdarzona licznymi talentami. Oddaje to poniższy fragment chwalący przymioty świętego:

[...] Bóg obdarzył swego sługę Kolumbana tak wielkimi darami, że wydawało się wręcz niepojętym, jak jeden człowiek może udźwignąć takie bogactwa. Jako potomek jednego z rodów królewskich Erin odziedziczył przymioty władców, takie jak szlachetność, męstwo, mądrość i sprawiedliwość. Był też utalentowanym bardem, jak mało kto w Erin [...]. Najwspanialszym darem [...] była jednak łaska kapłaństwa, która uzdalniała go do poznawania ludzkich serc i kierowania nimi oraz do nawracania niewiernych i grzeszników. By niczego mu nie brakowało, [...] Bóg dał mu nie tylko władzę nad sercami, ale także nad przyrodą, podobną do tej, którą posiadali pogańscy druidzi. Mocą modlitwy potrafił uciszać burze i morze oraz okiełznać dzikie zwierzęta. Dzięki modlitwie i postom udało mu się pewnego razu rozstrzygnąć wynik bitwy w Erin. Gdy się modlił, widział wokół siebie spoczywających na wzgórzach i drzewach aniołów Pańskich ${ }^{28}$.

19 Zob. I. Werbiński, Świętość jako zadanie dla każdego chrześcijanina, Toruń 2016, s. 11.

${ }^{20}$ Zob. ibid.

${ }^{21}$ Św. Bazyli Wielki, O Duchu Świętym, przeł. i przypisami opatrzyła A. Brzóstkowska, Warszawa 1999, s. 172.

${ }^{22}$ Ch. Schönborn, Przebóstwienie. Życie i śmierć, przeł. W. Szymona, Poznań 2001, s. 54.

${ }^{23}$ Zob. ibid., s. 42.

${ }^{24}$ Ibid.

${ }^{25}$ Zob. ibid, s. 54.

${ }^{26}$ Ibid.

${ }^{27}$ Ibid.

${ }^{28}$, ,.... [. Gott hatte seinen Diener Columba mit so vielen und großen Gaben begnadet, daß es beinahe unfaßbar scheinen wollte, wie ein einzelner Mensch eine so reiche Bürde tragen konnte. Nicht 
Kolumban prowadzi święte życie. Dobre czyny przychodzą mu z łatwością, gdyż Bóg wspiera go w jego misji. Nigdy jednak nie doświadczył poważnych przeciwności. Traktuje on świętość poniekąd jako właściwość, którą nabywa człowiek przebywający w bliskości Boga. Tak jak w judaizmie wszystko co przynależy do Boga lub ma z nim styczność, jest święte, tak również chrześcijański mnich z racji swojej roli, polegającej na służbie Bogu, wkracza do sfery sacrum. Kolumban próbuje zbliżyć się do świętości dzięki wysiłkowi ascezy, pracy i modlitwy oraz na drodze zaniechania korzystania z przyjemności, które oferuje człowiekowi świat doczesny. Choć jest zapewne świadomy roli łaski, bez której człowiek nie jest w stanie osiągnąć świętości, w praktyce polega najbardziej na własnym wysiłku i trudowi samodoskonalenia. Jego sposób myślenia i postępowania wskazuje na to, że zapomina o tym, iż każdy wysiłek w dążeniu do świętości stanowi jedynie odpowiedź na działanie Ducha Świętego. W praktyce uważa on odwrócenie się od sfery profanum i dbałość o czystość moralną za przepustkę do świętości. Tymczasem jak czytamy w Liście do Efezjan, trzeba ,,porzucić dawnego człowieka, który ulega zepsuciu na skutek zwodniczych żądz [...] i przyoblec człowieka nowego, stworzonego według Boga [...]"29. W 1 Liście do Tesaloniczan św. Paweł zwraca natomiast uwagę na miłość braterską, która w życiu zakonnym odgrywa wszakże szczególną rolę. Zachęca on członków wspólnoty chrześcijańskiej, aby „,coraz bardziej się doskonalili i starali [...] spełniać własne obowiązki i pracować własnymi rękami [...]"30, co również koresponduje z ideałem życia monastycznego. Zamiast służyć wspólnocie, Kolumban zdaje się jednak przede wszystkim podążać za własnymi ambicjami.

Irlandzki mnich ukazuje się czytelnikowi jako postać plastyczna, człowiek z krwi i kości. Współczuje Maurinn i nie potrafi się pogodzić z faktem, że unieszczęśliwia ją swoją odmową. Opis jego rozterek odnajdujemy w niniejszym fragmencie:

Świadomość, że nieszczęśliwa Maurinn [...] błądziła po wyspie lub czekała zatrwożona w swojej izbie, rozpraszała go i osłabiała jego siły. Te zaś jeszcze szybciej gasły w obliczu tęsknoty, która znów obudziła się w nim na widok krewnej. [...] Bolało go, że musi sprawić jej tak wielki zawód. Mimo mądrości i rozwagi, które zwykle pomagały mu we wszystkich

nur war er einem von Erins uralten Königsgeschlechtern entsprossen und hatte die natürlichen Gaben der Könige, Hoheit, Tapferkeit, Klugheit und Gerechtigkeit, in die Wiege gelegt bekommen. Er war zudem ein liedergewaltiger Barde, wie nur je einer in Erin [...] gewaltet hatte [...]. Das Herrlichste der Geschenke aber [...] war die Gnade des christlichen Priestertums, die ihn fähig gemacht hatte [...] die Herzen der Menschen zu kennen und zu lenken, Ungläubige und Sünder zu bekehren. Und damit nichts ihm mangle [...] hatte Gott ihm außer der Gewalt über die Seelen auch die Gewalt über die Natur gegeben, wie sie den heidnischen Druiden zu eigen war. Durch die Kraft seines Gebetes war er mächtig Stürme zu bannen, das Meer zu besänftigen und wilde Tiere zu bändigen, ja er hatte dereinst in Erin durch sein Beten und Fasten den Ausgang einer Schlacht entschieden. Während er betete aber, geschah es zuweilen, daß er auf Bäumen und Hügeln Gottes weiße Engel rasten sah“" (P. v. Preradović, Die Versuchung des Columba [w:] eadem, Gesammelte Werke, Wien 1967, s. 855-883, tutaj: s. 863). Wszystkie fragmenty noweli, przytoczone w niniejszym tekście, zostały przetłumaczone przez mnie [M. Sobczak].

${ }^{29}$ Pismo Święte Starego i Nowego Testamentu. Biblia Tysiaclecia, Poznań 2014, Ef 4, $22-24$.

${ }^{30}$ Ibid., 1 Tes 4,11. 
życiowych sprawach, tym razem nie wiedział, jak się ma w stosunku do niej zachować $[\ldots]^{31}$.

Kolumban zaczyna tęsknić za bliskimi. Tęsknota ta jest niezwykle silna, tym bardziej że ówczesne społeczeństwo irlandzkie oparte było na systemie klanowym. Przynależność do klanu odgrywała ważną rolę w życiu każdego Irlandczyka, zwłaszcza gdy wywodził się on ze sfer szlacheckich bądź arystokratycznych. Dzieciom od najmłodszych lat zaszczepiano poczucie lojalności wobec klanu, ten zaś dawał swoim członkom oparcie i zapewniał im bezpieczeństwo. Odejście od rodziny i porzucenie małej ojczyzny, będące konsekwencją wyboru życia monastycznego, uważano za szczególną formę wyrzeczenia. Mnisi iroszkoccy ${ }^{32}$ udawali się w odosobnione miejsca, aby się w nich osiedlić. Zwyczaj ten określano mianem peregrinatio pro Christo. Takim miejscem była między innymi Iona, niewielka wyspa, należąca do Hebrydów Wewnętrznych, na której Kolumban założył jeden z pierwszych klasztorów irlandzkich.

Bohater noweli przeżywa głęboki kryzys wiary, przypominający doświadczenie «ciemnej nocy zmysłów i ducha», opisane w XVI wieku przez hiszpańskiego mistyka i Doktora Kościoła, św. Jana od Krzyża. Niemiecki teolog, Günter Benker, scharakteryzował «noc ciemną» jako stan, w którym człowiek ,,bezpośrednio styka się z nicością, [...] doświadcza całkowitego opuszczenia przez Boga [...]"33. Chrześcijanie, którzy przeżywają ten stan, nie potrafią czerpać radości z modlitwy i medytacji. Czują się, jakby zostali porzuceni przez Boga. Zdaniem Benkera Bóg dopuszcza takie doświadczenie, gdyż w każdym człowieku są ,,[...] duchowe zniewolenia, które przeszkadzają mu [...] w zjednoczeniu z Bogiem oraz w dotarciu do samego siebie [...]"34. Wśród szkodliwych przywiązań Benker wymienia pychę, która paradoksalnie może wynikać z wcześniejszych doświad-

31 „Der Gedanke, daß die Jungfrau Maurinn unglücklich [...] auf der Insel umherirrte oder geängstigt in ihrer Kammer saß, schwächte und zerstreute seine Kraft, und noch schwerer wurde sie geschädigt durch das Heimweh, das beim Anblick seiner Verwandten neu in ihm geweckt worden war. [...] Es schmerzte ihn sehr, daß er seiner Blutsverwandten so bittere Kränkung zufügen mußte, und so umsichtig und weise er sonst in allen Dingen war, wußte er nicht, wie er sich gegen sie verhalten sollte [...]“" (P. v. Preradović, op. cit., s. 864-866).

${ }^{32}$ Kościół iroszkocki, nazywany także Kościołem iryjskim, był wczesnośredniowieczną organizacją kościelną na terenie Irlandii, Szkocji i Nortumbrii. Powstał po anglosaskim najeździe na Brytanię na przełomie V i VI wieku na skutek utraty kontaktu z Kościołem rzymskokatolickim. W drugiej połowie VII wieku podporządkował się władzy papieża. Miał odrębny ryt, własny sposób wyznaczania Wielkanocy oraz oparte na monastycyzmie struktury organizacyjne. Przeorowie i opaci niejednokrotnie odgrywali ważniejszą rolę od biskupów, kierując wspólnotami wiernych żyjących w otoczeniu klasztorów. Mnisi praktykowali surową ascezę, lecz w odróżnieniu od wielu wspólnot zakonnych w Kościele rzymskokatolickim utrzymywali kontakt z miejscową ludnością. Prowadzili działalność naukową, artystyczną i misyjną. Niejednokrotnie opuszczali klasztory, przenosząc się w nowe miejsca i osiedlając się wśród pogan. Praktyka ta doprowadziła z czasem do chrystianizacji Szkocji i Nortumbrii (zob. G. Krause, G. Müller (red.), Theologische Realenzyklopädie, Berlin-New York 1981; hasło: Keltische Kirchen (autor: Richard Sharpe), t. XVIII, s. 86-91).

33 G. Benker, Die «Dunkle Nacht» der Ganzwerdung. C. G. Jung und der Mystiker Johannes vom Kreuz, „Analytische Psychologie“ 1999, nr 30, s. 245-272, tutaj: s. 250.

34 Ibid. 
czeń duchowych ${ }^{35}$. Niemiecki teolog twierdzi, że przezwyciężenie zniewoleń możliwe jest jedynie dzięki Bożej interwencji ${ }^{36}$.

Irlandzki opat zostaje pozbawiony nadprzyrodzonych zdolności. Nie widzi aniołów, a światło, które zwykle wydobywało się z jego lewej dłoni podczas przepisywania psalmów, przestaje świecić. Próby uleczenia rannego brata Fursy okazują się bezowocne. Mnichowi wydaje się, że Bóg się od niego odwrócił. Paraliżuje go strach przed krajem Piktów, do którego zamierzał się udać, aby nawracać jego mieszkańców na wiarę chrześcijańską. Przed oczami jego wyobraźni stają straszne obrazy, w których on i jego współbracia są mordowani przez pogan. Niniejszy fragment opisuje rozterki Kolumbana:

Ogarnął go okropny strach przed chłodem i wrogością obcych krajów, do których chciał się
udać jako misjonarz. Zdawało mu się, że widzi tuż przed sobą pełne nienawiści oczy pogań-
skich kapłanów i czuje w swoim ciele niszczycielski wpływ ich czarów. Jeszcze nigdy nie
miał w sobie tak wielkiego lęku, paraliżującego duszę i rozum. Drżał, a jego skórę zrosił ob-
fity pot. Nagle ujrzał siebie i swoich towarzyszy, pomordowanych, pozbawionych prawa do
chrześcijańskiego pochówku, a ciała zbezczeszczone i rzucone ptakom drapieżnym na po-
żarcie. Nie potrafił sobie wyobrazić niczego bardziej przerażającego niż wypełnienie
postanowienia, które powziął już wiele miesięcy temu i które - mimo wahań - rozpoznał
jednoznacznie jako natchnienie Boże. Zaczął powtarzać na głos następującą myśl: «Już
najwyższy czas położyć temu wszystkiemu kres $)^{37}$.

Bohater doświadcza pokus i nie jest w stanie obronić się przed nimi. Środki, które dotychczas pozwalały mu na skuteczną walkę duchową, zawodzą. Wprawdzie zdaje sobie sprawę, iż odrzucenie zakusów złego jest zasługą człowieka, lecz zapomina, że oparcie się złu możliwe jest jedynie dzięki łasce Bożej. Nie dostrzega, iż wraz z postępami w pracy misyjnej zaczął polegać bardziej na sobie niż na Bogu. Realizację Bożych planów zastąpił zaspokajaniem własnych ambicji, przez co przestał podążać drogą uświęcenia. Wpadł w zachwyt nad własną doskonałością, popełniając tym samym grzech pychy.

Kolumban nie wie jeszcze, że został wystawiony na próbę, a jego dotychczasowy sposób postrzegania spraw nadprzyrodzonych ulegnie weryfikacji. Dusza człowieka doświadczającego «nocy ciemnej» zostaje oczyszczona z pychy i pragnienia doznań mistycznych oraz uwolniona od fałszywego obrazu Stwórcy ${ }^{38}$.

${ }^{35}$ Zob. ibid.

${ }^{36}$ Zob. ibid.

${ }^{37}$ „Es ergriff ihn eine grauenhafte Angst vor der kalten und feindlichen Fremde der Länder, in die als ein Bekehrer zu ziehen er sich vorgesetzt hatte; er glaubte den $\mathrm{Haß}$ in den Augen der heidnischen Priester dicht vor sich blitzen zu sehen und zu fühlen, wie die Einwirkungen ihrer zauberischen Künste sich vernichtend in seinen Körper einbohrten. Eine Furcht, wie er sie nie in seinem Leben empfunden hatte, lähmte seinen Geist und seine Seele, Schweiß brach ihm allenthalben aus der Haut, und er begann zu zittern. In Bildern des Grauens sah er sich selbst und seine Gefährten hingeschlachtet, noch als Leichen mißhandelt und ohne Gebet und christliches Begräbnis den wilden Vögeln zum Fraß überlassen. Nichts schien ihm fürchterlicher, als den Vorsatz auszuführen, den er nun schon Monde lang gehegt und wenn auch mit Zagen, so doch ohne zu zweifeln als Anruf Gottes erkannt hatte. Ganz laut vor sich hinsprechend, wiederholte er seinen letzten Gedanken: «Es ist Zeit, daß mit all diesem ein Ende gemacht werde»" (P. v. Preradović, op. cit., s. 876-877).

${ }^{38}$ Zob. G. Benker, op. cit., s. 250. 
W przypadku irlandzkiego opata przekonanie o możności wpływania na Boga stanowi poważną przeszkodę na drodze do świętości. Bóg wskazuje mu kierunek dalszego rozwoju poprzez całkowite zawierzenie. Dopiero gdy mnich uświadamia sobie swój grzech, zostaje wyprowadzony z ciemności. Zapewne dostrzega, że na drodze do świętości mogą go spotykać przeciwności, także natury duchowej. Trwanie przy Bogu w warunkach niesprzyjających ma znacznie większą wartość niż wtedy, gdy człowiek otrzymuje nadprzyrodzone wsparcie i ma poczucie obecności Boga. Wola wytrwania jest nieskuteczna, gdy nie zostaje umocniona łaską. Dążenie do świętości musi przede wszystkim wynikać z miłości do Boga i ludzi. Przypomina o tym chociażby Hymn o milośc $i^{39}$.

Kryzys Kolumbana kończy się, gdy z woreczka, podarowanego mu przez Maurinn, wysypują się zaczarowane zioła. Aby skłonić mnicha do opuszczenia wspólnoty zakonnej, kobieta postanowiła posłużyć się magią celtycką. Gdy wiatr rozwiewa zawartość woreczka, czar przestaje działać, a próba, na którą Kolumban został wystawiony, dobiega końca. Widzialnym znakiem oczyszczenia serca bohatera noweli staje się uzdrowienie rannego brata Fursy. Opat szybko zaczyna rozumieć, co się wydarzyło, dlatego wyzbywa się pychy.

W kontekście rozważań na temat świętości jest to bardzo istotny moment, gdyż zachowanie Kolumbana ilustruje, jakiej postawy instancja narracyjna oczekuje od człowieka. Ten, kto uległ złu, nie powinien w nim trwać. Umiejętność szybkiego powstawania jest prawdopodobnie najważniejszą cechą człowieka świętego. Nie jest on bowiem osobą wolną od niedoskonałości, która nigdy nie upada. Podobnie jak każdy inny człowiek, osoba święta jest słaba i ułomna. Jest to jednak ktoś, kto szybko staje na nogi i konsekwentnie walczy z grzechem, zastępując zło czynionym przez siebie dobrem. Prawdziwa wielkość Kolumbana polega na tym, że przystępuje on z miejsca do działania i z jeszcze większym zapałem wciela w życie Boże natchnienia. Będąc osobą o silnym ego, walczy z chęcią pogoni za nadzwyczajnymi dokonaniami, natomiast do kraju Piktów udaje się dlatego, że pragnie podążyć za Bożym wezwaniem. Nie ma to już nic wspólnego z krępującym miłość egoizmem i realizacją wybujałych ambicji. Od tej pory Kolumban faktycznie podporządkowuje swoje życie Bogu.

W noweli Pauli von Preradović odnajdujemy zatem cztery modele świętości, które ze sobą korelują. Na płaszczyźnie mistycznej świętość jest darem Boga i wezwaniem skierowanym do człowieka, a na płaszczyźnie ascetycznej jest odpowiedzią człowieka na Boże propozycje. Tak rozumiana świętość polega na odwróceniu się człowieka od sfery profanum, podejmowaniu trudu samodoskonalenia i dbałości o czystość moralną. Szczególną wartość ma wytrwałe pełnienie woli Bożej w niesprzyjających warunkach. Pozytywna odpowiedź człowieka na skierowane do niego wezwanie musi być w pełni dobrowolna. Trzecia koncepcja świętości wiąże się z dwiema poprzednimi. Zakłada ona, iż świętość polega nie tyle na skutecznej walce z grzechem i niedoskonałością, ile raczej na wytrwałym powstawaniu z upadku. Motywem takiego działania jest miłość do Boga. Ostatnia koncepcja wyrasta $\mathrm{z}$ judaizmu i polega na uświęceniu bytów mających styczność

\footnotetext{
${ }^{39}$ Zob. Biblia Tysiaclecia, op. cit., 1 Kor 13.
} 
ze sferą sacrum. Jest to tzw. świętość konsekracyjna. Przedstawione tu koncepcje świętości odnajdujemy także w innych dziełach prozatorskich austriackiej autorki.

Na pierwszy plan wybija się w noweli następująca myśl: człowiek często nie odnajduje w życiu właściwej drogi i traci z oczu cel swego doczesnego pielgrzymowania. Nad jego życiem czuwa jednak Bóg, który w krytycznych chwilach przychodzi mu z pomocą, wspierając go łaską. O ile tekst w pewnym sensie wskazuje czytelnikowi «właściwy» sposób postępowania w trudnych sytuacjach życiowych, o tyle nie ma on nic wspólnego z chrześcijańską literaturą dydaktyczną, gdyż nie przekazuje prawd i pouczeń o charakterze moralistycznym. Świat przedstawiony nie został ukazany w kategoriach czerni i bieli, dzięki czemu nowela pozwala lepiej zrozumieć istotę ludzkiej egzystencji wraz z jej dylematami i meandrami.

\section{Bibliografia (References)}

Benker G., Die «Dunkle Nacht» der Ganzwerdung. C.G. Jung und der Mystiker Johannes vom Kreuz, „Analytische Psychologie“ 1999, nr 30, s. 245-272.

Bleicher J.K., Literatur und Religiosität. Untersuchungen zu deutschsprachiger Gegenwartsliteratur, Frankfurt am Main-Wien (i inne) 1993.

Bruckmüller E. (red.), Österreich-Lexikon in drei Bänden, Wien 2004; hasło: Neuland, t. I, s. 475.

Gleń A., Jokiel I. (red.), Doświadczenie religijne w literaturze XX wieku, Opole 2006.

Jan Paweł II, Pamięć i tożsamość. Rozmowy na przełomie tysiącleci, Kraków 2005.

Kapfhammer F.M., Neuland. Erlebnis einer Jugendbewegung, Graz-Wien (i inne) 1987.

Kasper W. (red.), Lexikon für Theologie und Kirche, Freiburg im Breisgau-Wien (i inne) 1994; hasło: Columba(n) v. Hy (autor: Karl Suso Frank), t. II, s. 1267.

Krause G., Müller G. (red.), Theologische Realenzyklopädie, Berlin-New York 1981; hasło: Keltische Kirchen (autor: Richard Sharpe), t. XVIII, s. 86-91.

Kryszewski W., Marcinkowski R. (red.), Encyklopedia powszechna PWN, Warszawa 1985; hasło: Piktowie, t. III, s. 535.

Langenhorst G., Theologie und Literatur. Ein Handbuch, Darmstadt 2005.

Maren-Grisebach M., Methoden der Literaturwissenschaft, München 1973.

Molden E., Skizzen zu einem Porträt [w:] Paula von Preradović. Porträt einer Dichterin, Innsbruck 1955, s. 9-82.

Pismo Święte Starego i Nowego Testamentu. Biblia Tysiąclecia, Poznań 2014.

Otto R., Świętość. Elementy irracjonalne w pojęciu bóstwa i ich stosunek do elementów racjonalnych, przeł. B. Kupis, Warszawa 1999.

Preradović P. v., Die Versuchung des Columba [w:] eadem, Gesammelte Werke, Wien 1967, s. 855-883.

Röttinger W., Vorwort [w:] P. v. Preradović, Meerferne Heimat. Eingeleitet und ausgewählt von Werner Röttinger, Graz-Wien 1961, s. 5-23.

Schönborn Ch., Przebóstwienie. Życie i śmierć, przeł. W. Szymona, Poznań 2001.

Sobczak M., Das christliche Weltbild in der Prosa der österreichischen Dichterin Paula von Preradović, Kraków 2016. 
Św. Bazyli Wielki, O Duchu Świętym, przeł. i przypisami opatrzyła A. Brzóstkowska, Warszawa 1999.

Werbiński I., Świętość jako zadanie dla każdego chrześcijanina, Toruń 2016. 